\title{
Professional training of students as an object of quality management in the education system
}

\author{
V.I. Stymkovskij ${ }^{1}$, L.N. Anisimova ${ }^{2}$, I.I. Burlakova ${ }^{3, *}$ \\ ${ }^{1}$ The Department of Jurisprudence, Bauman Moscow State Technical University, Moscow 105005, \\ Moscow, Russia \\ ${ }^{2}$ Moscow State Regional University, Moscow 105005, Moscow, Russia \\ ${ }^{3}$ Academy of Social Management, Moscow 129344, Moscow, Russia
}

\begin{abstract}
The modern theory of quality management is based on the position that activities aimed at improving quality should be carried out in the process of production/service. It is possible to determine the quality of products/services by many factors, both objective and subjective. To prevent the impact of various factors on quality, a quality management system is necessary. Each country has its own concept of quality management, which reflects the essence of Total Quality Management (TQM) methodology to solve quality improvement problems. Quality models to a large extent coincide with each other, are mutually complementary and differ only in the completeness and depth of coverage of the work processes of the organization. The main purpose of our article is a comprehensive study of theoretical and practical issues of professional training of students on the basis of global quality methodology, its step-by-step description, identifying the practical value in use for both technical and humanitarian specialties.
\end{abstract}

\section{Introduction}

Having entered the era of globalization and having assumed the Bologna obligations to reform the system of professional education, Russia has undergone a long and difficult way of building education according to the given moulds. On the one hand, the modern stage of pedagogical science development, not only in our country but also abroad, is characterized by increased attention to the study of such integrative category as "quality of education". This category reflects its compliance with social and individual needs of people. There are numerous international studies which evaluate the quality of education in different countries, analyze the factors that affect the quality of education and ways of improvement in the leading educational systems of the world, establish rankings of states on this indicator. On the other hand, many modern politicians, scientists, public figures and teachers disagree, criticize education reforms and regret the lost past forever. Education is considered as an area of the global order, into which its structure has been transferred: general principles and standards - and various tasks assigned to institutions for the implementation of a common

${ }^{*}$ Corresponding author: iiburlakova@mail.ru 
global "educational space" [1]. We need to recognize the importance of modernizing the educational system due to the fact that conditions, factors, and the man himself have changed. Of course, it is difficult to live in the era of permanent reform. That is why there was a demand for a unified system, which would be effective and produce results that would satisfy both consumers of educational services and those who provide such services. The modern system of education is shaken by a great number of bureaucratic documents, which sometimes duplicate each other. We would like to remind you of the tried and tested system of managing the quality of education in general and the quality of professional training, in particular [2].

\subsection{Research Methodology}

The main purpose of our article is a comprehensive study of theoretical and practical issues of professional training of students on the basis of global quality methodology, its step-bystep description, identification of practical value in use for both technical and humanities specialties. The reliability and validity of the results of the conducted practice-oriented research was ensured by the general theoretical provisions and their correlation with the practical results obtained in the process of work in the department of educational process management. Also, we have used of valid tools and processing of the educational results obtained by us with their subsequent interpretation. In general, the methodological basis of the study consists of such general scientific methods as the collection of theoretical data on the problem of quality management, and its implementation in the practice of the university.

\section{Results}

\subsection{Results of the study}

The modern theory of quality management is based on the position that quality management activities will not be effective after the products have already been produced. Activities aimed at improving quality should be carried out in the process of product/service production. Quality assurance activities that precede the production process are of great importance. It is possible to determine the quality of a product/service by many factors, both objective and subjective. To prevent the influence of negative factors on quality, a quality management system is necessary [2].

Each country has its own concept of quality management, which reflects the essence of Total Quality Management (TQM) methodology for solving quality improvement problems. The national quality models are based on a process-system approach. They largely coincide with each other, are mutually complementary and differ only in the completeness and depth of coverage of the work processes of the organization.

In the general sense term «management» is a fairly common, but not standardized one. Scientific sources contain a large number of its definition. For example, according to D.M. Gvishiani at the end of the XX century there were more than 80 different definitions of the concept of management. In a broad sense, scientists understand management as a general function of organizational systems (biological, technical, social, pedagogical, etc.) that ensures the preservation of the integral structure, the maintenance of the functional mode, the realization of set goals through the achievement of certain results. In the narrow sense, management is administrative bodies, organizational structures, departments and units that perform managerial functions [3].

The modern stage of pedagogical science development not only in our country, but also abroad is characterized by increased attention to the study of such an integrative category as 
"quality of education", reflecting its compliance with the social and individual needs of people [4]. This is evidenced by numerous international studies, which evaluate the quality of education in different countries, analyze the factors that affect the quality of education and the ways of improvement in the leading educational systems of the world, establish rankings of states on this indicator. In recent years, we note the works of Mona Murshed, Chinesi Chiyoke and Michael Barber of the well-known McKinsey consulting company, which present the dynamics of changes in the quality of education in a number of countries $[5,6]$.

For more than 30 years in the system of Russian education we observe the development, adjustment and practical implementation of the methodology of quality management in higher education, related to the solution of a set of tasks:

- the first set of tasks is aimed at deep and comprehensive knowledge of the multidimensional object of management - the phenomenon "quality of professional training of students", structuring of public and personal needs, which are satisfied through the activities of the educational organization;

- the second set of tasks implies establishing, justifying and selecting the goal in the quality management system of students' professional training and its correlation with the benchmark; - the third set of tasks is aimed at finding forms, means and technologies to influence the controlled object - the quality of students' professional training - in order to achieve the planned results;

- the fourth set of tasks is aimed at implementing the quality management system of students' professional training, ensuring and maintaining its effective operation [2].

From the point of view of the authors of the article, special attention should be paid to the systemic, process and stage activity of quality management. This article is practiceoriented, we would like to dwell in more detail on the technology (stage) of quality management activities of students' professional training. So, the first stage involves planning activities based on the awareness and acceptance of the essence of the quality in professional training of students, the choice of appropriate goals and the creation of the main educational program.

The second stage is aimed at selecting means and technologies to implement the content of the basic educational program.

The third stage involves ensuring the quality of students' professional training through the operation of control.

And the fourth stage is aimed at correcting actions to improve the quality of students' training.

In general, according to the international standard ISO 9001:2000, we apply the methodology of "Plan-Do-Check-Act" (PDCA - Process Improvement Cycle by W. E. Deming) to all the above processes, which allows us to conclude on the possibility and feasibility of applying the methodology of international standard ISO 9001:2000 or its new version ISO 9001:2008 to quality management of students training [7].

According to A.V. Kiryakov's definition, students' professional training in quality management system of the university is a set of means and ways of organizing the activity of controlling and controlled subsystems. It provides purposeful change of educational process in order to give it the properties that guarantee the satisfaction of public and personal needs and state requirements for training specialists with specified quality indices [8].

This definition formulates a list of conditions necessary to implement quality management of students' professional training:

- scientific and methodological support of educational process quality management;

- functional change of educational organization, strengthening of developmental aspects of education;

- expansion of scientific and innovative activities of educational organization; 
- active introduction of information and distance technologies in the educational process, leading to a qualitative renewal of education;

- involvement of teachers in innovative activities, teachers' desire to improve their professional skills, increasing the personal responsibility of the teacher for the quality of educational results;

- improvement of mechanisms for certification of teaching staff, the introduction of an effective contract [9].

\subsection{Results discussion}

The main purpose of building a quality management system in higher education institution is the continuous improvement of professional training of highly qualified specialists, capable of effective work at the level of national and world standards, ready for professional development in a knowledge-intensive economy. In this case the management provides the quality of students' professional training by integrating numerous components, which include: the quality of curricula, teaching materials, used educational technologies; quality of teaching (quality of the teaching staff); quality of students' independent learning activities; quality of knowledge and developed skills; quality of additional education, innovation activity of university, material and technical resources. The quality of students' professional training, and, consequently, the income and losses of the university in the conditions of extrabudgetary financing necessity are mediated by achieving certain results of students' professional training quality. For any modern university this position is relevant due to the fact that the number of students who study on a contractual basis is increasing annually. The implementation of educational programs in the university, which meet the needs of all stakeholders can lead to both economic and social effects [2].

The basic principles on which the quality management system of students' professional training is based and developed coincide with the key principles of quality management specified in the international standard of ISO 9001:2008 series [10]. Being the basis of the theory and practice of quality management of students' professional training, the principles have a certain behavioral value in addition to rational influence. They accumulate, catalyze, stimulate, determine the movement of the entire staff team towards continuous quality improvement.

The regulatory basis for the concept of quality management system for professional training of students in all Russian universities is formed by the state regulatory documents in education, adopted in the Russian Federation since 2000. In accordance with the requirements of the International Standard ISO 9001:2000, the quality system is characterized as a system of coordinated activities for university management and administration in relation to quality. In general, the quality management system of education should consist of three subsystems [11]:

- quality management in system of higher education;

- the system of quality in students' professional training;

- the system of quality assurance of students' professional training.

Quality management of students' professional training of students is considered as a result and as a process. Quality management is based on documentation, which describes all the processes and sub-processes, as well as the actions of the process participants aimed at achieving the required level of quality. The documentation of quality management system includes: quality policy, regulatory and working documentation for all areas of university activities, enterprise standards. In general, the system of quality assurance of students' professional training includes the main aspects of the university activities, which include a 
number of indicators that affect the quality of students' professional training to a greater extent.

The first group of indicators includes indicators that characterize the overall structure of students' professional training, the areas of training implemented in the university, basic educational programs, programs of all disciplines, teaching complexes, training tools, the share of students involved in research work [12].

The second group of indicators includes the university activities aimed at improving the quality of professional training of graduates, including the identification of data on the participation of students in various competitions, contests, research grants [12].

The third group of indicators includes the state of the quality assurance system in the university:

- the quality of the teaching staff and its activities (the share of teachers with academic degrees, the share of teachers awarded with governmental and other awards, certification of professional development);

- the content of the main educational program, programs of academic disciplines and educational-methodical complexes;

- the used educational technologies, including modern information and distance technologies, the state of the educational and methodical support of educational activities;

- the amount of research work per teacher (including the presence of publications in foreign journals), the amount of fundamental and applied research in the form of state assignments and grants, the relationship of research activities with the educational process;

- the variety of forms of research students and the available practical experience in this area of activity;

- material and resource support of educational activities [12].

The documentation of the quality assurance system includes: basic educational programs, department plans, regulations on structural units and job descriptions, long-term teacher training plans, development programs of the university, departments, student education program.

The quality assurance system includes:

- annual self-evaluation reports of the activities of the university and departments;

- surveys and questionnaires for staff, students and graduates;

- system of quality control of the graduates training for professional activities;

- diagnostics of the personal development (moral, intellectual, value-motivational, physical); the level of professional development;

- corrective actions.

\section{Conclusion}

Experience shows that if the system functions successfully enough, then the quality system exists in one form or another. Therefore, the task of the university is to improve the quality management system. Proven traditional quality improvement procedures require not only the addition of new documents, but also their unification.

Thus, our vision of the quality management system of professional training of students is based on the fact that this system should be, first of all, open, developing and innovative. In other words, the system should be mobile (flexible) in its interaction with the external environment and be able to adapt, restructure, economically and pedagogically interpret the educational request of the consumer, provide search for new ways and means of solving problems arising both in the internal and external environment. This understanding of the quality management system of professional training of students is reflected in the priority provisions of the policy in the field of quality of education [13]. Scientifically based quality 
management of professional training of students will be the most perfect if it is carried out with maximum consideration of the requirements of the international standard ISO 9001:2000 or its updated version ISO 9001:2008.

\section{References}

1. K. Maltsev, A. Alaverdyan, A. Maltseva, National and State Classical University in the context of modern globalization, International Scientific Forum on Sustainable Development and Innovation (WFSDI 2021), Patras, Greece, 295 (2021). DOI: https://doi.org/10.1051/e3sconf/202129505004

2. I. I. Burlakova, Management of quality education in modern university: issues of theory and practice, Quality education: problems and prospects. Collection of scientific articles, 40-50 (2016)

3. D. M. Gvishiani, Organization and Management (M.: Publishing house of Bauman Moscow State Technical University, 1998)

4. M. Barber, M. Mourshed, Consistently high performance: lessons from the world's top performing school systems, McKinsey and Company (2007)

5. M. Barber, M. Mourshed, Shaping the Future: How Good Education Systems Can Become Great in the Decade Ahead, Report on the International Education (Rountable, Singapore, 2009)

6. M. Mourshed, C. Chijioke, M. Barber, How the worlds most improved school systems keep getting better (2010)

7. E. Deming, The way out of the crisis. A new paradigm of managing people, systems and processes $=$ Out of the Crisis (Alpina Publisher, 2011)

8. A. V. Kiryakova, Quality of education as a pedagogical problem A. V. Kiryanov Quality of professional education: provision, control and management, Materials of the AllRussian scientific-practical conference, 25-35 (2003)

9. S. V. Golosova, L. P. Fedorenko, The main paradigms of modern pedagogical science, Scientific_methodical electronic journal "Concept", 53, 36-40 (2016). Access mode: http://e koncept.ru/2016/76035.htm

10. ISO 9000:2008, Quality Management systems -Requirements = International standard: Quality management system. Requirements (Text), translation and scientific and technical editing (M.: Standardinform, 2009)

11. ISO 9000:2000, Quality Management systems - Fundamentals and vocabulary = International standard: Quality management system. Basic provisions (text), translation and scientific and technical editing by All-Russian Scientific Research Institute of Certification of the Gosstandart of Russia (Moscow, 2001)

12. I. Burlakova, G. Khoroshavina, L. Anisimova, Personality-oriented education as a factor of sustainable development of the higher education system, International Scientific Forum on Sustainable Development and Innovation (WFSDI 2021), Patras, Greece, 295 (2021). DOI: 10.1051/e3sconf/202129505012

13. O. A. Pavlova, N. I. Chirkova, I. I. Burlakova, Building a practice-oriented model of preservice teacher education, SHS Web of Conferences, International Scientific and Practical Conference "Teacher Professionalism: Psychological and Pedagogical Support of a Successful Career" (ICTP 2020), 00094 (2020) 